\title{
Wasbington Hotline
}

\section{@ your library copyright}

In the new 107 th Congress, we expect database legislation to again be high on the agenda. Regulatory proceedings will continue, primarily through the Copyright Office at the Library of Congress. And ALA is heavily involved with copyright-related litigation, notably the Tasini $v$. New York Times and DVD cases. (See the ALA Web site for further information at http://www.ala.org/washoff/ property.html.)

"How have copyright laws changed over the last few years, and how does this impact the work of libraries?" The answer is short and disturbing: Copyright laws have changed dramatically, and the social role of libraries is threatened because of these recent changes.

For example, recent amendments to copyright law passed by Congress, including the Digital Millennium Copyright Act (DMCA) and the Sonny Bono Copyright Term Extension Act, favor the interests of copyright holders over the interests of the public. The DMCA allows copyright holders to use technological means to prevent access to a copyrighted work.

Copyright holders and copyright permission services are developing mechanisms to exact payment for fair uses. Technological protection devices can measure and track use of digital copyrighted materials so users can be charged for all unauthorized uses, even those unauthorized uses that are lawful, like fair use. This means that libraries and library users can be charged for printing a fair use copy of a journal article, or copyright even a paragraph from a copyrighted work.

Permission services like the Copyright Clearance Center are actively pursuing libraries and asking that they pay an annual license fee to cover unauthorized copyright of copyrighted materials, primarily from journal publications, even though the libraries have lawfully purchased the materials and have paid a high institutional journal subscription price.

Lynne E. Bradley is Office of Government Relations director of ALA's Washington Office; e-mail: leb@alawash.org
Now more than ever, academic librarians must remain informed and involved-ready to be active in grassroots advocacy to preserve fair use and work on the multitude of other policy issues that impact library users and library services.

The current trends in copyright law are not good for our nation's libraries, but there are steps that academic librarians can take to reverse these trends:

1. Stay informed. Participate in the copyright educational opportunities ALA offers. This spring, ALA will launch its first distance education course on copyright via the Web. The ALA Office for Information Technology Policy (OITP) will continue to offer e-mail tutorials on copyright, UCITA, and other topics on its copyright Web site at http://copyright.ala.org

2. Get involved. Write to your congressional representatives to voice your concerns. Use the Washington Office Legislative Action Center (http://congress.nw.dc.us/ala/) for help in writing letters and contacting the appropriate Congressional decision-makers. Stay in touch with the ALA Office of Government Relations (OGR) and attend National Library Legislative Day (April 30 and May 1, 2001).

3. Most important: Embrace your role as a librarian. Now more than ever our society needs librarians to focus on the public interest. Demand that users of digital information have the same rights as users of print information and that all of our citizens have equal access to information.

We need more academic librarians involved in these battles if we are to keep rights, such as fair use, for our library users and our institutions. There are other issues, such as the reauthorization of the Library Services and Technology Act (LSTA) and a legislative proposal from the National Commission on Libraries and Information Science (NCLIS), related to the dissemination of government information that also impact academic libraries. Watch for more on these issues in future columns.-Carrie Russell, Copyright Specialist, ALA Wasbington Office in the Office for Information Tecbnology Policy 


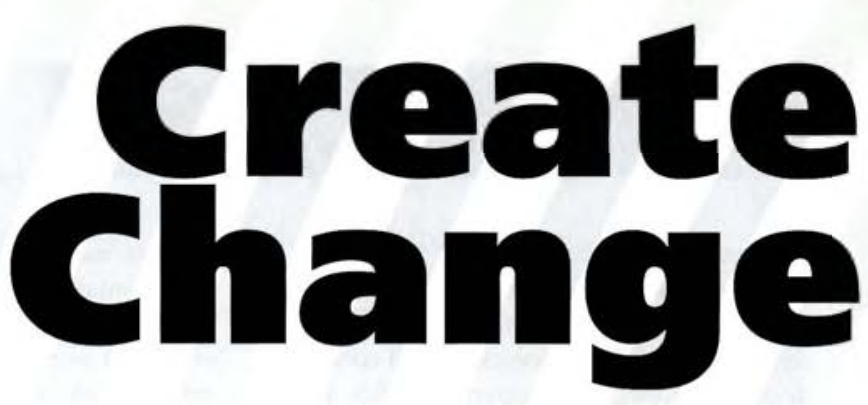

Keeping track of what's new in scholarly

communications can be a full-time job.

For the latest news, participate in

\section{a roundtable discussion}

Creating Change:

Scholarly Communications in Transition

\section{ACRL 10th National Conference, Denver}

March 16, 2:30-4:00 pm, Room A201

Join in a wide-ranging discussion on trends and opportunities.

- Creating change in your institution: Organizing a local scholarly communication advocacy initiative.

- Open Archives: Key to the future of scholarly communication?

- Introducing Declaring Independence - a new resource to help journal editors explore their options.

- Aggregating content, aggregating customers: The Big Deal; consortia's role in creating change.

Panelists include:

- Carl Lagoze, Open Archives Initiative;

- Ken Frazier, Director of Libraries, University of Wisconsin;

- Sarah Michalak, Director, University of Utah Libraries;

- Kristin Gerhard, University of Iowa Library;

- Rick Johnson, Enterprise Director, SPARC.

- Moderator: Ray English, Director,

Oberlin College Libraries.

For more information: wwww.arl.org/sparc or sparc@arl.org 